\title{
DANCING TO ARCHITECTURE: POPULAR MUSIC, ECONOMIC CRISIS AND URBAN CHANGE IN 1980S INDUSTRIAL EUROPE
}

\section{A B S T R A C T}

This article examines popular music practices in industrial cities during the time of economic downturn and crisis (the early 1980s). In particular it takes into account the birth of alternative DIY musical practices and their use of urban space at the imaginary and material level.

The article will start with an introduction to music making and to the effects it has on space / place perception and use. I have examined case studies from industrial cities and compared the way different music scenes developed during times of crisis and achieved relevant cultural expressions.

The main interest of this paper is to show how the economic downturn brought to a series of cultural innovations, which were not directly connected to technological advance and resulted out of re-use, recycle or innovative use of available technologies and practices. 


\section{INTRODUCTION}

In the beginning of 2012, the City of Birmingham Leisure, Sport \& Culture Overview \& Scrutiny Committee published a report entitled 'Destination Birmingham, Birmingham, A Music City'. The study examines past and present popular music and produces a detailed list of recommendations on possible ways to direct it into boosting local economy.

Lately, popular music heritage, especially in English former industrial centres, has become a valuable ingredient in the local tourist offer, in form of local bands, genres and individual artists, gaining international fame between the 1950s and the 1980s and through dedicated museums, guided tours and events. In addition, contemporary music festivals, nightclubs and local musicians have further consolidated cities association to popular music and consequently to excitement, youth, liveliness and novelty.

Birmingham attempt has proved successful on the international level for instance in Liverpool, with The Beatles heritage industry ${ }^{2}$ and in Austin with $\mathrm{SXSW}^{3}$, but also disastrous in Sheffield with the National Centre for Popular Music $^{4}$. This has affected also non-strictly industrial cities in non global scales: Seinajoki (Finland) attracts national tourists during its Tango Festival (Heinonen 2012) and forgotten Italian seaside resorts Rimini and Riccione are resurfacing as centres of the electronic music italo-disco revival. Furthermore, this trend also had consequences for classical music: Bayreuth image is built around the Festspiele and Vienna showcases itself in live broadcasting through the New Year's concert of its Philarmoniker.

All these examples should be contextualized within contemporary urban branding, i.e. the attempt undertaken by cities all over the world to acquire some distinctiveness and popularity by adopting corporate marketing strategies ${ }^{5}$. The symbolic value associated to cultural practices such as music is widely recognized as a key to succeed in the global competition for resources, wealthy inhabitants, tourists and companies. However, this relation can be seen at least as two-folded: not only cities are profiting from music but also music itself has increasingly made use of places. In the 1990s for instance all US bands seemed to originate from Seattle ${ }^{6}$ and all British bands from Manchester ${ }^{7}$. Nowadays, in a global music market of niches, the connection with a place anchors an artist in a particular atmosphere, taste, era or genre, sometimes in unpredictable and contradictory ways, such as the case of Handsome Furs and Helsinki (Bottà, And They're Sitting on Thousands of Bodies! Popular Music, City and Media 2009). 
Memorial feature films, (auto)biographies and glossy photo books are also widely celebrating the connection between popular music and cities. Forgotten artists are revamping their careers by becoming 'place witnesses', no more as much representing an era (as in the roaring twenties, the swinging thirties or the magic sixties), but rather expressing certain timeless local features. It seems that 'dancing to architecture' is no more a rhetorical figure explaining the absurdity of 'talking about music', as in the rather famous quote, attributed to Frank Zappa, Elvis Costello and many others ${ }^{8}$, it defines an apparently genuine and natural gesture of responding to place.

This increasingly significant link has been explained in a wide range of ways, either arising from a change in the regimes of accumulation ${ }^{9}$ or dependant on the tastes of the creative class ${ }^{10}$. Ethnographic and cultural historical methods also showed the impact of popular music on cities renewal and preservation. ${ }^{11}$

It is sure that, with some exceptions ${ }^{12}$, there is a widely accepted agreement on a contemporary notion of what a place is and on the role that popular music 'plays' in it. Place has become a signifier for 'authentic' derelict districts, often imbued in recent history, highly valuable from the real-estate point of view and therefore on the verge of being gentrified. These locations are often to be found on the fringes of capital city centers, they might be former working class districts, offering affordable rents in shared flats easy to sub-let, populated mostly by a mixture of students, immigrants and petty criminals. Partly because being connected to a certain collective experience in the life of many citizens, these districts are highly romanticized within the city narrative. The 'authenticity' of these places is never put into question, nor is their connection to popular music. Popular music determines their 'place-ness', just like the palimpsest of graffiti, flyers and posters on walls, the prevalence of dilapidated red brick constructions hosting bars, clubs, record shops and cafes and the precarious balance between legalities and illegalities.

This paper however deals with a particular kind of place (the industrial city) and with a peculiar form of popular music (hardcore punk), under very specific circumstances (economic crisis and deindustrialisation in the early 1980s). In this kind of setting, instead of students we might encounter workers or unemployed unskilled youth, instead of vintage red brick constructions, bare concrete and instead of graffiti and flyers, just broken windows. I wish to analyze specific articulations of the relationship between space and popular music and therewith to overcome on one hand the common understanding of the 'place of music' and on the other, the oversimplified, pacified and accepted 
notion that makes 'dancing to architecture' not only plausible, but also welcome by city municipalities.

The relation between popular music and urban change will not be therefore read as connected to logics of creativity and poetics of place, but as articulated within specific spatial and economic regimes. In particular, I will consider how the 1980s economic downturn and deindustrialization brought to a series of cultural innovations, which were not directly connected to technological advance; they were based on re-use and recycling or on the innovative use of widely available technologies, agencies and practices.

\section{THE INDUSTRIAL CITY}

In the European context, the industrial city is generally regarded as an urban typology belonging to planning and architectonical history. Contemporary discourses surrounding it contain keywords such as preservation, heritage and restructuring and have been sealed by the 2010 election of the Ruhr Metropolis to European Capital of Culture. Nonetheless, for almost three hundred years the industrial city responded to the needs of a capitalist regime based on manufacturing and industrial production by maintaining one sole paradigm: production. This kind of city was not designed for consumption, not even in its centre; nor for services (excluding the basic ones), it was designed to facilitate, enforce, and embed production.

Of course in the millenarian history of European urbanization, there have been examples of mono-functional cities before, for instance cities of commerce, port towns, administrative centres and leisure cities, but none of these categories has had such a deep impact on modern Europe as the industrial city ${ }^{13}$.

The origins of the industrial city are set in the 'shock towns' of the $18^{\text {th }}$ Century Lancashire, with Manchester as its prime example. These former rural towns of Northern England were deeply transformed because of industrial manufacturing; they grew with a vertiginous pace and without any form of urban regulation and planning of sort. The pace of manufacturing and the dominance of British industrial concerns on vast areas of the world required industriousness in massive scales and a continuous in-flow of labor forces.

Already in 1845, Friedrich Engels was able to describe the inextricable urban design of Manchester, where rich and poor lived in spatial proximity 
without ever meeting each other. ${ }^{14}$ The workers were squeezed into unhealthy and quickly built or reconverted lodgings, without social facilities or leisure spaces. It took decades before urban planning began regulating the needs of capitalist industries and workers acquired the consciousness of their rights, bringing forward the concept of welfare and wellbeing. Certain materials became typical of industrial cities and their use widespread: red bricks in the $19^{\text {th }}$ and the bare concrete in the $20^{\text {th }}$ century.

The use of béton brut in the $20^{\text {th }}$ century brought to the conception of new industrial- and mass-tailored architectonical styles, from Le Corbusier functionalism ${ }^{15}$ to the British new brutalism ${ }^{16}$, legitimating acquiescence to fordism and to the newly established 'scientific' rules of mass production.

Le Corbusier saw the house as a machine, as a tool, legitimizing production as the sole determinant of architectonical aesthetics and ethics:

Eradicated from your mind any hard and fast conceptions in regard to the dwelling-house and look at the question from an objective and critical angle, and you will inevitably arrive at the "House-Tool", the massproduction house, available for everyone, incomparably healthier than the old kind (and morally so too) and beautiful in the same sense that the working tools, familiar to us in our present existence, are beautiful. ${ }^{17}$

Nowadays, brutalism and functionalism are mostly associated to dereliction, segregation, migration and urban crisis; deindustrialization hit very hard and very sudden, exactly when these architectonical styles were used the most. Their clear exhibition of structures and materials showed very well the interruption of their functioning or the downgrading of their inhabitants' economic power. The period under consideration is ruled by specific neo-liberal policies, practiced particularly in the UK by Prime Minister Margaret Thatcher and in the US by President Ronald Reagan, by energy crises, political turmoil and a series of economic inflations and recessions. All these factors brought to a change in economic paradigm in many European countries. The heavy industry began its still ongoing transfer to cheaper and less controlled developing countries. ${ }^{18}$

Many European industrial cities were left to their destiny by national governments: they shrank, imploded, citizens left, many residential and industrial areas lost much of their real estate values and were destroyed or sealed out, waiting for better times. The human costs have never been taken into account properly, but a generation or two of (ex-) working class individuals had to deal with unemployment and often related depression to suicide. 
Slowly many former industrial cities began understanding themselves as postindustrial, following a sociological thought. ${ }^{19}$ They re-imagined themselves as sites for a new economic regime based on services, technology and flexible accumulation. Success stories, like Baltimore in the US or Bilbao in Spain fuelled the thirst for reprisal. Re-conversion of industrial premises into residential, education- or service-related use became very popular. Distancing from the industrial past was paralleled by a wide-ranging fetishisation of its atmosphere of decline.

According to Böhme, atmosphere is a spatial concept, which does not arise both from the subject nor from the object, although it maintains object-like and subject-like features. ${ }^{20}$ Atmosphere is the space allowing objects to articulate their presence, however it is also sensed in bodily presence by subjects, it is a subject's state of being in space. Böhme's definition of atmosphere makes sense of the modes of relation between object and subject in spatial constellations.

Lehtovuori describes Helsinki's makasiinit, a former railway warehouse, later appropriated as site of various cultural events in Helsinki, until its destruction in 2009, with these words:

'Firstly, the rough aesthetics, scars of time, smell of wood and tar and the historic allusions of hand-made bricks, steel trusses and other paraphernalia all contributed to a special atmosphere that attracted users and underlined the value of a different place in the increasingly sanitized city centre. Secondly, the size of the buildings and the rail-yard, their form reminiscent of a town square, their direction vis-à-vis views and flows, and the fluid, sieve-like spatial organization, originally made to facilitate quick movement of goods through the warehouses, are all specific configurational qualities that explain why the buildings were so well-suited for various events and other temporary uses. The atmospheric and configurational analyses help to understand how, precisely, the material artefact of Makasiinit was valuable as a 'living' and connected socio-spatial (socio-material) reality'. ${ }^{21}$

The author never openly claims that the atmosphere of the place can be classified as 'industrial', although this seems to me a key element in understanding the fascination that the Makasiinit exerted on Helsinki citizens. The Makasiinit radiated their industrial atmosphere in an augmented way, because of their location, in the very centre of a capital city, known for its culture and for its political role (and not so much because of its industry). The fact that the Makasiinit lied a few meters from the stairs of the Finnish Parliament collaborated further in tweaking the modality of its atmosphere. 
Talking about an industrial atmosphere always implies the reverberation of certain perceived or imagined industriousness, brutalism, roughness, rhythm, murkiness and noise emanating from street corners, empty buildings, means of transportations, public squares, encounters, faces, appearances and styles, possibly in all social and material realities.

Different cultural traditions and representations created a huge array of narratives about less educated, louder, dirtier industrial city inhabitants and about their attitude. For instance in the British context, from Charles Dickens to kitchen sink films, from madchester music scene to Coronation Street soap opera, the bleak industrial towns of the North have been celebrated as 'the land of the working class'. ${ }^{22}$

Even more important is the fact that an industrial city has little symbolic or branding value, when compared to other urban centres. Just by pronouncing out loud 'Paris', 'London', 'Prague' or 'Turin', 'Tampere', 'Duisburg', it is very easy to determine the toponymies, which reverberate in our imaginary and the ones, which remain more anonymous and empty. There is still little placevalue connected to industrial cities because these cities were born without proper connotations outside the world of manufacturing and production. The attempt to shift their place-value to culture and creativity is fairly new and the results have been too unlike to determine their overall success. One of the reasons behind the impact of the industrial atmosphere could as well lie in this indeterminacy, with the difficulty to read it within the above-mentioned notion of place. The post-industrial city has been a sometime desperate attempt to bring the notion of place within this atmosphere and by transforming it into a historically funded cultural expression. Music has played an important role in this attempt and the next paragraph will examine this.

POPULAR MUSIC AND THE INDUSTRIAL CITY

\section{Settings}

Looking at the history of popular music and focusing on the 1980s, it is possible to determine that disparate genres like post-punk, heavy metal, electronic music originated in decaying industrial cities in the north of England (Manchester, Birmingham and Sheffield respectively).

Other industrial second cities, in non-Anglo Saxon contexts weren't less creative. In particular, I am going to focus on Turin (Torino, in Italy), Tampere (Finland) and the Ruhr urban conurbation (Germany) to determine the impact of popular music in industrial settings of Nordic, central and southern 
European regions. The three settings are deeply dissimilar in size, but are coherent regarding national scales and the function of these cities within the three different national contexts.

The development of Turin as an industrial city increased exponentially during the economic boom of the 1950s, thanks to the automobile industry. Massive migration of workforce from the south of the country, the building of huge dormitory districts and the political struggle of the 1970s have been strong elements in the image of Turin within Italy, although of course, industrialism used to characterize many other centres, especially in the north (Milan for instance). ${ }^{23}$

Popular music in Turin became extremely politicized in the 1980s with the establishment of a 'collettivo punks'. Bands from Turin such as Franti, Indigesti, Negazione, and Quinto Braccio developed an autonomous scene, which for a brief period established links in Europe and the US through extensive touring and the production and release of cassettes and LPs, which were distributed through independent networks. ${ }^{24}$

Tampere carries the nickname Manse, a Finnishized 'Manchester' because of its industrial textile past and the presence of extensive industrial architecture and canals. Nowadays much of the industrial heritage of the city has been converted into museums and other cultural or entertainment facilities. The independent record label Poko Rekords started its activities in 1977 and released the most important records of Finnish rock bands such as Yö, Eppu Normaali, Popeda, Hassisen Kone, and Sielun Veljet, linking inevitably a certain sound to the Finnish town. ${ }^{25}$ In addition, a politicized hardcore punk scene developed from the 1980s with bands such as Kohu-63, Riistetyt, Kaaos, Tampere SS and Bastards.

The Ruhr is an immense industrial area in the very core of western Germany and continental Europe, whose growth challenged the definitions of 'city' and 'region' within the European context. ${ }^{26}$ In the 1980s, especially in centers like Duisburg, Oberhausen and Marl, a scene with bands (Sons of Sadism, Tu-Do Hospital, Hostages of Ayatollah, ...), squats and clubs started gathering fans.

The Rhythm of the Factory: History of a Misunderstanding

From contemporary classical music to house electronic music, from soul to heavy metal, a huge range of musical genres have been associated to the 'sound of the factory'. This sound is usually used in reference to repetitive and mechanic beats, very low frequencies, distortion and dissonance, all 
elements, which depending on the listener, can be identified in a variety of popular music genres. It is sure that the 'sound of the factory' has a rhythmic and a melodic connotation to it, both apparently funded on noises originating in sites of manufacturing. Of course, the sounds coming from a factory vary a lot according to the materials produced, to the resonance provided by walls and the way it is perceived outside or inside its premises, and by the way work is organized and carried out.

Nonetheless, the rhetorical force of this association still lingers on. Its success can be best grasped by its nearly immediate adoption to describe youth music since the post-war era. Genres like rock and roll or blues relied on loud electric amplification (both at the level of live shows and recordings) and were therefore often compared to undistinguishable noise by non-fans and by older generations.

Another important element is the construction of the popular music persona. In this context, the working class origin is regarded in many genres as an undisputed requirement to determine the authenticity, therefore often the success, of a particular band or performer. Associating your sound to the factory, often imply your direct involvement with manufacturing and the 'working class hero' status.

Third, the association to the industry provides a very specific imaginary localization of sound. Music in itself is in fact rarely able to communicate with the same clarity of language or of a visual cultural expression like cinema. In interviews, narratives about industrial sounds fund the poetics of a certain performer more than reference to the use of certain chord progressions or melodies, which often are unknown and difficult to understand for listeners.

There is a specific music genre, which is referred to as 'industrial music' and its origins are often associated to real industrial cities (1980s Manchester, Sheffield, West-Berlin) and bands such as Throbbing Gristle, Clock DVA or Einstürzende Neubauten (Duguid). Nonetheless, these bands might as well be understood in the context of avant-garde, which was experimenting with industrial noise already in the beginning of the $20^{\text {th }}$ century; for instance Alexander Mosolov's ‘The Iron Foundry' and Arseny Avraamov's ‘Symphony for Factory Whistles' incorporate a huge array of industrial and urban noises. ${ }^{27}$

The simple reference to the place where they have been produced cannot fund fully and plausibly industrial sounds as musical elements. The 'rhythm of the 
factory' should therefore be understood as a worn out and vague metaphor, which is not productive enough, when examining the innovations which took place in industrial cities of the 1980s in relation to music practices. It is a rhetorical tool, which links place and music in a fashion, which has been very productive in the last twenty years. First of all, it liberated industrial cities of their desolate, anonymous and indeterminate atmosphere, maintaining some (ad hoc sanitized) aesthetic traits alive, for the joy of the so-called creative class. In addition, it gave an opportunity to remove any oppositional element from music, making it a profitable local heritage.

\section{Squatting space with noise}

The 1980s represent a very misconceived era of western European history. Edonism (yuppism) in society, conservatism in politics and postmodernism in arts dominate the decade's canonization. From the urban point of view, the 1980s are known for the step from managerialism to entrepreneurialism in city councils and from industrial to postindustrial in economic paradigm. New flexible regimes of accumulation affected cities planning and increased the wealth of a few.

However, these years also represented a continuum in some alternative cultural practices born in the 1960s and 1970s, especially in urban industrial contexts. Punk was born as an aesthetic and musical experiment, originating in London and New York City, thanks to typical 'big city' synergy of fashion designers, musical performers, media channels, svengalis, talent scouts, impresarios, curators, record companies, investors and of course a mass of citizen/consumers/fan/hangers-on. DIY (do it yourself) and bricolage are believed to be the major innovations of punk. Hebdige refers to 'semiotic guerrilla warfare', a concept originally from Umberto Eco, when interpreting punk use of bricolage; he abstracts it as a subversive appropriation and recombination of symbols. ${ }^{28}$

It is however important to consider that, in the end of the 1970s, DIY was a widespread popular practice in relation to house furnishing, gardening and clothing, responding to times of economic distrust and austerity. ${ }^{29}$ In the work of designer Vivienne Westwood and svengali/impresario Malcolm McLaren DIY became a way to implement a new total aesthetics to be marketed and sold through traditional fashion and music industries. ${ }^{30}$

In my view, it is only in 'second' cities that DIY becomes an instrument of individual and urban innovation, thanks to a material lack of other means. As 
Lättä, the singer of Kohu-63, a band from Tampere active since 1976, puts it: You had to cope with the stuff you were able to get your hands on. You didn't go to a store to buy a distortion pedal back then. I remember some store selling an assembly kit that you could buy and make yourself a distortion pedal. I had a tube radio and a guitar and my guitar had these old fashioned microphones with magnets. I broke that magnet in three pieces and reassembled my guitar and then I got some distortion to the sound. You had to come up with these kinds of solutions back then. ${ }^{31}$

In this short reminiscence, DIY is more connected to skills in electricity work than to ideologies or aesthetics. The true nature of punk as innovative work, lies more on self-initiative and the re-use and re-cycle of the existing than on a subversion at the level of symbols.

In particular, I am interested in revealing the role that sound played in these centres as Ersatz for public sphere. Following Jürgen Habermas' classic definition of Öffentlichkeit, public realm relates to the discursive action of civil society legitimizing the state ${ }^{32}$. In addition, it is commonly accepted that the negotiation of identities and shared meanings always happens in public. Third, the term has legal and economic connotations, as shown by the on-going debates surrounding economic crisis, public expenditures and state bankruptcies around Europe, the public is something that belongs to the people and it should be handled with care. There are certain entrepreneurial risks that a private company can take but that a public institution shouldn't. However, it is on the street, that all these features of the public materialize, coexist, and come together: there, it is possible to come together with same-minded people, hang out, perform an own identity, dramatize the own status in society, confront not same-minded people; there, demonstrations take place in name of the people; there, social differences become evident and there, state power exercises its control over individuals. As pointed out by Doreen Massey social relations are always spatial; space and 'the social' are inextricable from each other. ${ }^{33}$ Whenever we are talking about private and public, we are talking about ways to define both social and spatial relations.

Punk scenes in industrial cities were able to rearticulate the private vacant industrial spaces, into public ones, both materially (by gathering in them) and at the imaginary level (by using them in pictures, lyrics and sounds). However, they also occupied public spaces and made them 'private', winning them as sub-cultural territories. Nonetheless, their main effort was the creation of a counter-public realm from below situated in music itself. Music became the most important means to communicate, protest, occupy, and subvert the industrial city and its status. 


\section{INNOVATIONS AND THE ECONOMY}

For this paper, I have interviewed several musicians, active in Turin (Italy), Tampere (Finland) and in Ruhrgebiet (Germany) in the early 1980s. I have also collected an adequate corpus of recordings of these bands (mostly digitalized 7 " and cassettes or recent CD and LP anthologies), live videos and fanzine interviews of the time. These bands are mostly associated to the hardcorepunk scene and its derivates, which combined a fastening up of punk riffs and rhythms, the extensive use of DIY in music production and distribution and the politicization of lyrics (mostly connected to anarchism). Seminal bands of the $\mathrm{HC}$ scene are from the US (i.e. Black Flag, Dead Kennedys, Minor Threat) and UK (i.e. Crass, Discharge, Disorder, The Exploited) bands, but big scenes developed in several other countries. ${ }^{34}$

The big difference with previous sub-cultural or scene-related musical happenings was its cosmopolitanism: very quickly, thanks to a continuous trade of 7", tapes and fanzines and the use of letters and telephone calls, a sort of global autonomous network developed. Unsigned bands were able to tour for longer periods, relying only on the help of other band members or local organizers.

One of first wide-European compilation 7" within this context (many cassette tapes were available already before) is Papi, queens, reichkanzlers and presidennti (sic), produced by Attack Punk Records in Bologna (Italy) in 1984. The bands involved are six, each present with one song: Irah (from Bologna), Total Chaos (from Tyne \& Wear), Quinto Braccio (From Turin), Stromsperre (from West-Berlin), Kaaos (From Tampere), Sottocultura (from Bologna) and Kollettivo (from Turin). The record is completely self-produced by the label, the songs have probably been given for free by the bands, in exchange of a few copies, all revenues are reinvested in future productions.

The 7" is a format normally used by record companies to promote a hit-singles (on the a-side, normally including on the b-side a minor song not available on the long playing album) and it traditionally plays on $45 \mathrm{rpm}$; its cover is normally a very simple sleeve, with a cover and the track-list on the back.

The 7" under consideration contains six songs, there is no a and $b$ side, the sides are called 'logo' and 'black' referring to the label in the centre of the vinyl. The two sides play with different rpm: logo with 33 1/3 (normally used for LP) and the black side in the classic $45 \mathrm{rpm}$. There is a cover and a backside, but also a thick booklet, containing bilingual (Italian and English) information about this 
specific production, its aims, the label back catalogue and other statements by Attack Punk Records. Each bands is given a space for lyrics (in case translated into English from the national language), addresses, political statements, lyrics explanations, and band logo. The cover is a simple single color drawing, of a Bosch-inspired infernal animal/machine with the faces of pope John Paul II, England's queen Elizabeth, Finnish president Koivisto and German chancellor Schmidt attacked by a punk holding a broom. Running on one side of the cover is the statement 'do not pay more than 2000 lire / 1 pound'.

This is just one of the hundreds of 7" tapes traded around the world, sharing the above-mentioned features: cosmopolitanism, DIY, reinvestments of the profit in the scene, price-control, use of $33 \mathrm{rpm}$ to extend possible playing time and include more songs, inclusion in the cover folder of a poster containing manifestos, lyrics, addresses, technical help to help producing further music supports.

I decided to extensively describe this 7", among the hundreds I might have chosen, for several reasons. First of all because of the geographical spread that it encompasses: from Tampere to Turin there are $2700 \mathrm{~km}$ and at the time, five border controls to undergo; from West Berlin to Tyne \& Wear about 1700 $\mathrm{km}$, including a journey across a concrete wall and on a motorway where it was forbidden to stop. Second, this small piece of vinyl also testifies of the centrality of unknown, anonymous industrial centres and 'second' cities within this scene. Tampere, Torino, Bologna, Tyne \& Wear, West-Berlin were in the 1980s industrial peripheral areas, variously affected by regional, national, European and global economic and political crises, economic inflation and deindustrialization, causing unemployment, urban shrinking and the appearance of big empty vacant spaces.

Talking about innovation in relation to this specific artefact (the 7") or to the hardcore punk scene in general means addressing a very narrow definition of what innovation is. Surely, it is not connected to technological innovation, but photocopy machines, vinyl records, the phone, postal service, typing machine, electric music instruments (guitar, drums, bass) recording studios had been invented and were commonly available decades before the hardcore punk scene developed. It cannot be defined an organizational innovation either: sport clubs, religious associations, collectors' groups, political parties and other music scenes were also widely networking at a European level often using the same DIY instruments available to this particular scene: telephone, barter and xeroxed fanzines and address lists. 
The main innovatory effort of this particular scene was connected to different factors than the mere technology related ones. First of all, it is an innovation at the level of cultural sensibility, which I defined elsewhere as an individual or collective reaction to certain social or spatial circumstances, which asserts a certain aesthetic or emotional value to a particular place. ${ }^{35}$ This shall not be understood as a mere change in appreciation or in taste, it has more to do with the dramatization of a particular human condition.

Certainly, a parallel to the industrial decay sensibility can be found in the fascination for ruins, common for the European Neo-classical and Romantic movements. ${ }^{36}$ Nonetheless, in those particular cases, ruins were metaphors for the inevitability of death and decay (memento mori) or reflections of the complex artist's inner life and their appreciation was connected to a certain cultural capital and individual status. In addition, the temporal distance between the sensible subjects and their material object made the economic dimension completely irrelevant.

It is common in every European city to find a former factory turned into a theatre, a media facility or a restaurant, sometimes with grotesque results. However, an abandoned factory is just the expression of a local or global change at the level of capitalist accumulation, which affected manufacturing or production. It is cultural sensibility and its spreading from the individual to the collective level, to add a particular symbolic value to the material building and to make it 'pleasant' and 'inspiring' enough to become an art gallery for instance. There are of course very clear logistic elements to it, i.e. the size, illumination and location; nonetheless its appeal originates in the cultural sensibility of an individual or a few.

What previously has been described as 'industrial crisis atmosphere' is therefore not something given, but it has an origin in a specific socio-economic context: the 1980s urban crisis and in relation to a specific group of people, which I identify with the hardcore and post-punk scenes developing in the 1980s in European and north American industrial cities.

A second kind of innovation comes from the emphasis on communitarian, democratic, no-profit, ecological and sustainable practices, completely antithetical to the traditional music industry and to capitalism as a whole.

Despite ideological disputes (available to read in a huge number of fanzines), legal issues, police control, cultural or economic exploitations and individual 
fails, several scenes, groups, individuals were able to keep this kind of spirit alive for years and sometimes still do.

\section{A MATTER OF PERSPECTIVE}

The cultural turn in disciplines such as geography, urban studies and architecture brought to a shift in the notion of place and of its relation to space. Place began to be increasingly understood as 'culturalized space'; an authentic expression of an organically evolving and truly communitarian public space. This notion had a deep impact in a series of other academic fields such as history $^{37}$ and literary studies ${ }^{38}$. Increasingly, also popular culture, tourism marketing and the public opinion became members of the congregation of believers in the sacredness of place.

Place began to signify a certain kind of urban upbeat environment only, imbued by the patina of recent history, preferably with a wireless cappuccino café at hand. The industrial crisis atmosphere, as long as sanitized and available in cities with high real estate prospects or realities, also became a feature of place. Airports and malls are classified as non-places i.e. places of transit and shopping, without any history and possible attachment, while natural, peripheral, industrial areas continue to be mere articulation of space, anonymous spots where innovation cannot be made profitable.

The industrial city did not become a signifier of place; it first had to transform itself into a 'post-industrial' one, i.e. undergo a process of architectonical renewal and revitalization, a reconfiguration of its economic paradigm, a reimagining of its self-representation and self-understanding and a reorganization of its inward and outward circulation dynamics. It had to become safer, cleaner and more aesthetically pleasant, fighting for recognition on the global scale with completely new instruments and on a completely new arena. Hardcore punk music also faded and retreated into a niche; some of its features were appropriated and popularized later by a variety of alternative but not oppositional scenes ranging from heavy metal to emo, from grunge to indie.

Analyzing industrial cities and its relation to a distinctive kind of musical practice, which was born and became popular in it, means dealing with lack of identity and direction during the crisis. It reveals the citizens' attempt to dramatize their own condition sonically and to occupy city spaces with speed and noise. It offers no clear solution to the industry demise, but it shows 
how creativity can flourish independently from supposed poetics of place, which normally hide nothing else than mere expectations for revenues and real estate speculations. Birmingham City Council, 2012). (Aldershot: Ashgate, 2007). "Austintatious"?," Foundations and Trends in Enterpreneurship 6, no. 4 (2010): 239-313. Adam Brown, Justin O’Connor, and Sara Cohen, "Local Music Policies Within a Global Music Industry: Cultural Quarters in Manchester and Sheffield," Geoforum 31, no. 4 (2007): 437-451. Cordula Weiss-Sussex and Franco Bianchini. Urban Mindscapes of Europe. (Amsterdam: Rodopoi, 2006). 
Adam Krims, Music and Urban Geography (New York, London: Routledge, 2007).

Richard Florida, “The Changing Geography of Pop Music,” The Atlantic, February 17, 2011.

Cohen, Decline, Renewal and the City in Popular Music Culture: Beyond the Beatles.

Krims, Music and Urban Geography.

Peter Clark, European Cities and Town (Oxford: Oxford University Press, 2009).

Fredrich Engels, The Condition of the Working Class in England in 1844 (Oxford: Oxford University Press, 2009)

Le Corbusier, Towards a New Architecture (New York: Dover, 1986).

Laurent Stalder, “'New Brutalism', 'Topology' and 'Image': some remarks on the architectural debates in England around 1950,” The Journal of Architecture 13, no. 3 (2008): 263-281.

Corbusier, Towards a New Architecture, 263.

Barry Eichengreen, The European Economy since 1945 (Princeton and Oxford: Princeton University Press, 2007).

Daniel Bell, The Coming of the Post-Industrial Society (New York: Basic Books, 1976).

Gernot Böhme, "Atmosphere as the Fundamental Concept of a New Aesthetics," Thesis Eleven 36 (1993): 113-126.

Panu Lehtovuori, “Towards Experiental Urbanism,” Critical Sociology 38, no. 1 (2012): 77-87.

Rob Shields, Places on the Margin: Altenative Geographies of Modernity (London: Routledge, 1991).

Nicola Tranfaglia, Storia di Torino XI: Gli Anni della Repubblica (Torino: Einaudi, 1999).

Beppe De Sario, Resistenze Innaturali: attivismo radicale nell'Italia degli anni ottanta (Milano: Agenzia X, 2009).

Terhi Skaniakos, Discoursing Finnish Rock: Articulations of Identities in the Saimaa Ilmiö Rock Documentary (Jyväskylä: University of Jyväskylä, 2010).

Johannes Springer, Christian Steinbrink and Christian Werthschulte, Echt! Pop-Protokolle aus dem Ruhrgebie. (Duisburg: Salon Alter Hammer, 2008).

Alex Ross, The Rest is Noise: Listening to the Twentieth Century (London: Picador, 2008).

Dick Hebdige, Subculture The Meaning of Style (London: Routledge, 1979).

Paul Atkinson, "Do It Yourself: Democracy and Design," Journal of Design History 19, no. 1 (2006): 1-10.

John Savage, England's Dreaming: Sex Pistols and Punk Rock (London: Faber and Faber, 1991). Lättä, interview by Giacomo Bottà. Interview Translated by Severi Helle. Tampere, (November 2011).

Jürgen Habermas, "The Public Sphere: An Encyclopedia Article.” New German Critique, no. 3 (1974): 49-55.

Doreen Massey, John Allen and Steve Pile. City Worlds (London: Routledge, 1999), 157.

Steven Blush, American Hardcore: A Tribal History (Washington: Feral House, 2001) and Helge Schreiber, Network of Friends: Hardcore-Punk der 80er Jahre in Europ. (Duisburg: Salon Alter Hammer, 2011).

Giacomo Bottà, "The city that was creative and did not know: Manchester and popular music 1976 - 1997," European Journal of Cultural Studies 12, no. 3 (2009): 349-365.

Paul Zucker, "Ruins: an Aesthetic Hybrid." The Journal of Aesthetics and Art Criticism 20, no. 2 (1961): 119-130.

Karl Schlögel, Im Raume lesen wir die Zeit (München: Karl Hansen, 2003).

Franco Moretti, Atlas of the European Nobel 1800 - 1900 (London: Verso, 1998). 
Atkinson, Paul. "Do It Yourself: Democracy and Design.” Journal of Design History 19, no. 1 (2006): 1-10.

Böhme, Gernot. "Atmosphere as the Fundamental Concept of a New Aesthetics." Thesis Eleven 36 (1993): 113-126.

Bell, Daniel. The Coming of the Post-Industrial Society. New York: Basic Books, 1976.

Berend, Ivan D. An Economic History of Twentieth Century Europe. Cambridge: Cambridge University Press, 2006.

Blush, Steven. American Hardcore: A Tribal History. Washington: Feral House, 2001.

Bottà, Giacomo. "And They're Sitting on Thousands of Bodies! Popular Music, City and Media." In Culture and the City, by Frank Eckardt and Louise Nyström, 43-58. Berlin: Berliner Wissenschafts-Verlag, 2009.

—. "Nordic Oddity: Putting Helsinki on the City-Break Map." Language and the Scientific Imagination: Proceedings of the 11th Conference of Issei. Helsinki: Language Centre, University of Helsinki, 2010.

Bottà, Giacomo. "The city that was creative and did not know: Manchester and popular music 1976 - 1997.” European Journal of Cultural Studies 12, no. 3 (2009): 349-365. 
Brown, Adam, Justin O’Connor, and Sara Cohen. "Local Music Policies Within a Global Music Industry: Cultural Quarters in Manchester and Sheffield." Geoforum 31, no. 4 (2007): 437-451. Clark, Peter. European Cities and Towns. Oxford: Oxford University Press, 2009.

Cohen, Sara. Decline, Renewal and the City in Popular Music Culture: Beyond the Beatles. Aldershot: Ashgate, 2007.

Corbusier, Le. Towards a New Architecture. New York: Dover , 1986.

De Sario, Beppe. Resistenze Innaturali: attivismo radicale nell'Italia degli anni ottanta. Milano: Agenzia X, 2009.

Duguid, Brian. "A Prehistory of Industrial Music.” www.synesthesie/heterophonies/historique/ Duguid-Prehistory.html (accessed April 3, 2012).

Eichengreen, Barry. The European Economy since 1945. Princeton and Oxford: Princeton University Press, 2007.

Engels, Fredrich. The Condition of the Working Class in England in 1844. Oxford: Oxford University Press, 2009.

Florida, Richard. "The Changing Geography of Pop Music.” The Atlantic, February 17, 2011.

Habermas, Jürgen. “The Public Sphere: An Encyclopedia Article.” New German Critique, no. 3 (1974): 49-55.

Haslam, Dave. Manchester, England. London: Fourth Estate, 2000.

Hebdige, Dick. Subculture The Meaning of Style. London: Routledge, 1979.

Heinonen, Yriö. "Seinäjoki tanssi ja soi: kaupunkitilan festivalisoituminen tangomarkkinoiden aikana." In Tango Suomessa, by Antti-Ville Kärjä and Kai Åberg, 181-217. Jyväskylä: Nykykulttuuri, 2012.

Krims, Adam. Music and Urban Geography. New York, London: Routledge, 2007.

Lättä, interview by Giacomo Bottà. Interview Translated by Severi Helle. Tampere, (November 2011).

Lehtovuori, Panu. “Towards Experiental Urbanism.” Critical Sociology 38, no. 1 (2012): 71-87.

Massey, Doreen, John Allen, and Steve Pile. City Worlds. London: Routledge, 1999.

Moore, Ryan. Sells Like Teen Spirit. New York City: NYU Press, 2009.

Moretti, Franco. Atlas of the European Nobel 1800 - 1900. London: Verso, 1998.

O'Toole, Garson. November 08, 2010. quoteinvestigator.com/2010/11/08/writing-about-music/ (accessed April 2, 2012).

Overview \& Scrutinity. Destination Birmingham. Birmingham A Music City. Birmingham: Birmingham City Council, 2012.

Phillips, Ronnie J. "Arts Enterpreneurship and Economic Development: Can Every City Be “Austintatious"?" Foundations and Trends in Enterpreneurship 6, no. 4 (2010): 239-313.

Ross, Alex. The Rest is Noise: Listening to the Twentieth Century. London: Picador, 2008.

Savage, John. England's Dreaming: Sex Pistols and Punk Rock. London: Faber and Faber, 1991.

Schlögel, Karl. Im Raume lesen wir die Zeit. München: Karl Hansen, 2003.

Schreiber, Helge. Network of Friends: Hardcore-Punk der 80er Jahre in Europa. Duisburg: Salon Alter Hammer, 2011.

Shields, Rob. Places on the Margin: Altenative Geographies of Modernity. London: Routledge, 1991.

Skaniakos, Terhi. Discoursing Finnish Rock: Articulations of Identities in the Saimaa Ilmiö Rock Documentary. Jyväskylä: University of Jyväskylä, 2010.

Springer, Johannes, Christian Steinbrink, and Christian Werthschulte. Echt! Pop-Protokolle aus dem Ruhrgebiet. Duisburg: Salon Alter Hammer, 2008.

Stalder, Laurent. "'New Brutalism', 'Topology' and 'Image': some remarks on the architectural debates in England around 1950." The Journal of Architecture 13, no. 3 (2008): 263-281.

Tranfaglia, Nicola. Storia di Torino XI: Gli Anni della Repubblica. Torino: Einaudi, 1999.

Weiss-Sussex, Cordula, and Franco Bianchini. Urban Mindscapes of Europe. Amsterdam: Rodopoi, 2006

Zucker, Paul. "Ruins: an Aesthetic Hybrid." The Journal of Aesthetics and Art Criticism 20, no. 2 (1961): 119-130. 
PLES ZA ARHITEKTURU:

POPULARNA MUZIKA, EKONOMSKA KRIZA I URBANA PROMENA

$U$ INDUSTRIJSKOJ EVROPI OSAMDESETIH GODINA XX VEKA

\section{Giacomo Bottà}

Ovaj članak istražuje prakse popularne muzike u industrijskim gradovima u vreme ekonomskog pada i krize ( ranih osamdesetih dvadesetog veka). Posebno uzima u obzir rađanje alternativnih URADI SAM muzičkih praksi i njihovo korišćenje gradskog prostora na imaginarnom i materijalnom nivou. Članak počinje uvodom u stvaranje muzike i u efekte koje ona ima na percepciju i korišćenje prostora / mesta. Ja sam istraživao studije slučajeva iz industrijskih gradova i upoređivao način na koji su se različite muzičke scene razvijale u vremenima krize i postigle relevantan kulturni izraz.

Glavni interes ovog rada je da se pokaže kako je ekonomski pad doveo do niza kulturnih inovacija, koje nisu neposredno bile povezane sa tehnološkim napretkom a prostekle su iz ponovne upotrebe, recikliranja ili inovativne upotrebe rasploživih tehnologija i praksi.

KLJUČNE REČI: POPULARNA MUZIKA, INDUSTRIJSKI GRAD, INDUSTRIJSKI PAD, BRUTALIZAM, PANK, MESTO I MUZIKA, INDUSTRIJSKA ATMOSFERA 